\title{
ARTICLE \\ Retail Outlets and City Centrality: Perspectives from a Sub-Saharan African City
}

\section{Eti-obong Simeon Ema*}

University of Uyo, Nigeria

\begin{tabular}{|c|c|}
\hline ARTICLE INFO & ABSTRACT \\
\hline $\begin{array}{l}\text { Article history } \\
\text { Received: } 1 \text { November } 2019 \\
\text { Accepted: } 12 \text { November } 2019 \\
\text { Published Online: } 30 \text { November } 2019 \\
\text { Keywords: } \\
\text { Retail outlets } \\
\text { Sub-Saharan africa } \\
\text { Central business district } \\
\text { Uyo urban }\end{array}$ & 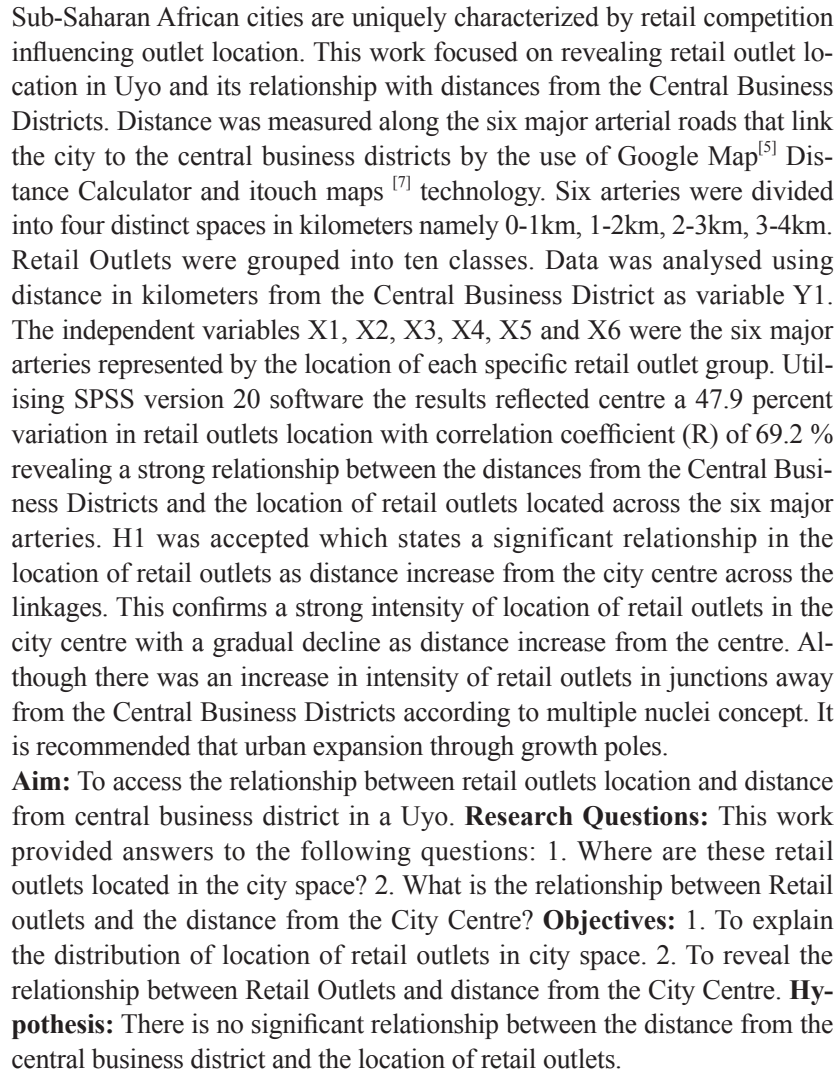 \\
\hline
\end{tabular}

*Corresponding Author:

Eti-obong Simeon Ema,

University of Uyo, Nigeria;

Email:eti_ema@yahoo.com 


\section{Introduction}

$\mathrm{E}$ very geographic problem may contain three elements. It must specify what and where and must ask why ${ }^{[9]}$. Geographers are concerned with diverse phenomena on the surface of the earth. To understand these features and its consequences on man, questions like; what is it? where is it located? why is it there? and what is the significance of the location? Posing these questions, seek responses that will help to organize spatial understanding by revealing the pattern of location of retail outlets in urban centres and the consequences of its location and associations. Most Nigerian cities are scarcely planned and thus are ill prepared for the surge in urban explosion that results from the rural urban migration and the growth that made most Nigerian cities what they are today, a decadence of humanity ${ }^{[2]}$.

Furthermore, most modern research on the location of retail outlets were built on studies that focused on the description of the location and causes of these locations of retail outlets in cities in the developed countries. Thus, there exist gaps in knowledge on how retail outlets are distributed in a city in the developing countries taking Uyo a major city in the Niger-delta region of Sub-Saharan Africa as an example. While other research take location of retail outlets in isolation, this work will add something new to existing knowledge by revealing its relationship with. Currently, there is limited information on the way retail outlets are located and the effect of these location on the quality of the urban environment of a developing country.

\subsection{Socio-Economic Activities}

Uyo urban experienced socio economic explosion when it emerged as the state capital city of Akwa Ibom State in Nigeria in 23rd September, 1987. Its major city market was popularly called Urua Etuk and a satellite market Urua Itam. Currently, Uyo has several major traditional markets which include but is not limited to Urua Akpan Andem, Itam, Ifa, Ekpiri Nsukara, Nwaniba. Uyo had functioning companies like Champion Breweries, Plastocrown, and Quality Ceramics in its City space. Other conspicuous institutions in Uyo include; the University of Uyo, Uyo City Polytechnic, Ibom Tropicana, Five Star Hotel, Akwa Ibom e-library, Akwa Ibom Water Company, Nigerian Post Office, different branches of Banks, Telecommunication Service Providers, public and private primary Schools, different Churches to mention but a few.

Uyo is a commercial and administrative city as the State is governed from Government House, Wellington Bassey Way. There exist both public and private sectors of the economy where majority of the middle income class are Civil Servants with other occupation like traders and artisans (tailors, carpenters, barbers, brick layers, e.t.c) having its fair share of space. It is also worthy to note the large amount of tricycle popularly call Keke napep (named after the Nigerian MDG's National Poverty Eradication Programme (NAPEP)) riders claiming dominance in the cities transport and economic space. Uyo has an averagely good road network with limited.

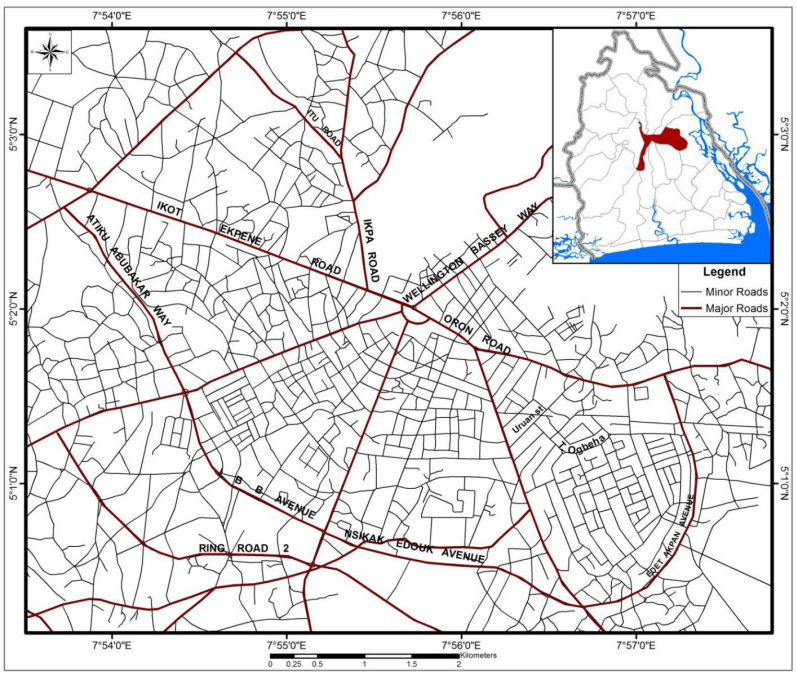

Figure 1. Streets on the Map of Uyo Urban

Traffic jams which mostly occur during the transportation peak periods from $7.30-9.30 \mathrm{am}$ and $3.00-7.00 \mathrm{pm}$. This traffic jams occur in mostly populated retail areas. During this traffic peak, street hawkers make brisk sales to motorist and passengers.

The most popular form of transportation around Uyo urban is via Keke where each drop is from NGN50 (USD0.14) and above depending on the distance involved. Though, the popularity of Keke mode of road transportation is being challenged by the growing patronage of Taxi. This is because of the restrictions of the Ministry of Transport where no Keke policy is enforced around the Central Business District in order to reduce traffic jam in the city space. There is a growing commercial night life where various types of goods are displayed for sale by street hawkers who keep their wares on the road and do brisk business by attracting potential customers returning home from work. This commercial night life peaks from $5 \mathrm{pm}-10 \mathrm{pm}$ daily and concentrates at the Central Business District (Ibom Plaza), sprawling along Keke napep terminals on Ikot ekpene road, Aka Road and Oron Road.

\subsection{Conceptual Classification}

Concentric Zone Model: Ernest Burgess quest to explain the distribution of urban social structures within urban areas in 1923 proposed a model which explains the different 
land uses in an urban centre. Burgess model disclose that land uses are arranged based on concentric rings starting from the central business district located at the centre of the model. He elaborated that these rings expands with different land uses. The first Zone being the CBD comprises of civic, social and commercial land uses, the second Zone contains industrial, residential (modern, obsolete and slum) land uses, the third Zone classed as belt of working class housing which he insisted were occupied by families migrating outwards from the second Zone and still had the need to live close to where there are working. Second-generation immigrants into the city are an important element of this third Zone .He emphasized that Zone four had single - family abode populated by the middle-class groups interspaced with exclusive residences and high class apartment buildings. While Zone five is at the fringe of the urban area which he named commuters Zone characterized as former rural areas gradually evolving into areas with dormitory like settlements where commuters travel every day to work. This Zone and the urban area are separated by continuously built-up area of green belt. This model as proposed applies to certain aspects of Uyo urban space though limited in its explanation of the role roads play in land use determination.

Relating this concept to the Uyo urban reveals an identifiable central business district also known as the city centre which is popularly referred to as Ibom plaza see Fig 1. This Zone consists mostly of civic, social and commercial land uses. The second Zone though limited in the industrial land uses, has most modern and few obsolete residential land uses. Our concern within this model is in its layout of commercial land uses. It states that Central Business District (CBD) is the centre of the concentric zone followed by the transition zone of mixed commercial and residential uses he called zone of transition. While there are series of clusters of retail outlets along Burgess proposed transition zone, retail outlets are not limited to this location. Thus, we need to logically explain its location along linkages and other locations outside of the transition zone but still within the urban space.

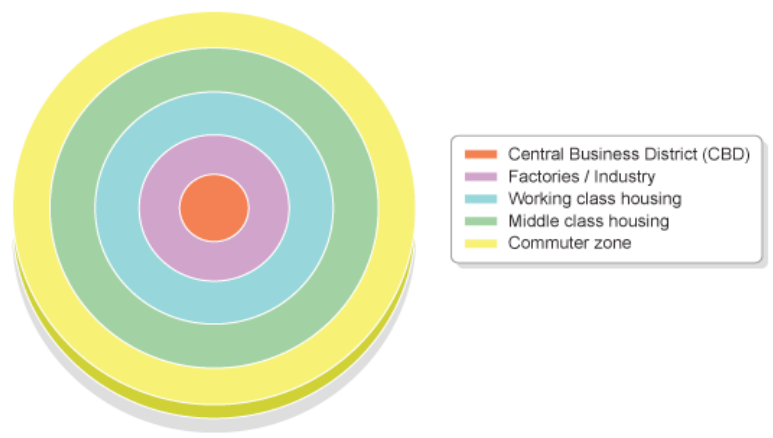

Figure 2. Concentric Zones

Source: GCSE Bitesize, $2016^{[3]}$.

\section{Methodology}

\subsection{Research Design}

In order to achieve the objectives of the study, this research design used quantitative methodological paradigm techniques in data collection to enhance validity and reliability. Data was analyzed using Multiple Correlation statistical techniques.

\subsection{Methods and Sources of Data Acquisition}

Data was collected from the field through the actual counting of the different classes of retail outlets as points in space in the sampled areas. The distance from the Central Business Districts was measured along the six major arterial roads that link the city to the central business districts by the use of Google Map Distance Calculator and itouch maps technology. The six arteries were divided into four distinct spaces in kilometers namely $0-1 \mathrm{~km}, 1-2 \mathrm{~km}$, $2-3 \mathrm{~km}, 3-4 \mathrm{~km}$. A collection of the ten classes of retail in a zone according to their location across the four distinct spaces with the linkages were carried out. Secondary data was sourced from journals, articles as referenced.

\subsection{Population of the Study}

This study was focused on Uyo urban area and the entire retail outlets in the sample area. The 2015 population of the study area was projected from the 2006 National Population Commission, (NPC) 305,961 persons using the formula;

$$
P o=\operatorname{Pt}\left(1+\frac{r}{100}\right)^{n}
$$

where: $P$ o $=$ Projected Population

$\mathrm{Pt}=$ Population of the base year

$\mathrm{r}=$ rate of growth $(2.3)$

$\mathrm{n}=9$ years

Applying the formula $P o=305,961\left(1+\frac{2.3}{100}\right)^{9}$

gave a projected population of 375,445 persons for the study area.

\subsection{Determination of the Sample Size}

The determination of the sample size was based on Cochran ${ }^{[1]}$ formula:

$$
N o=\frac{(t)^{2} *(p)(q)}{(d)^{2}}
$$

Where $\mathrm{t}=$ value for selected alpha level of .025 in each tail $=1.96$ 
$(p)(q)=$ estimate of variance $=.25$

$\mathrm{d}=$ acceptable margin of error for proportion being estimated $=.05$

$\mathrm{No}=$ determination of sample size

$$
N o=\frac{(1.96)^{2}(.5)(.5)}{(.05)^{2}}=384 \text { respondents }
$$

This gave a sample size of 384 respondents for the study. The respondents were retailers who frequently shop in retail outlets in Uyo urban. The questionnaire was designed to collect primary data aimed at revealing the effects of location of retail outlets from consumers, retailers and respondents found around retail outlets in Uyo urban.

\subsection{Sampling Techniques}

A reconnaissance survey of Uyo urban was carried out, and for the convenience of data collection, the area of study was delineated into six zones according to the six major arterial ways. The area in between Ikot Ekpene and Abak Roads made up zone A, Abak and Aka Roads zone B, Ikot Ekpene Road and Wellington Bassey Way zone $\mathrm{C}$, Wellington Bassey way and Nwaniba Road zone D, Nwaniba and Oron Roads zone E, while Oron and Aka Roads made up zone F as adopted from research of diverse retail outlets by Sarwar, Chowdhury \& Muhibbullah ${ }^{[10]}$, Tom ${ }^{[11]}$. Furthermore, zonal delineation aided in revealing the spatiality of retail outlets in Uyo urban as compared to the popular Sector model by Hoyt ${ }^{[6]}$. Each zone as delineated had two sampled Collectors linkages, two sampled Local linkages and two sampled Arterial linkage where 10 questionnaire was administered in each with an exception of the Major Arterial road where 14 questionnaire was administered. Thus, 64 copies of the questionnaires were administered in each zone. A systematic sampling method was adopted in selecting the sampled streets. Two roads were systematically chosen based on the classes of linkages which are Arterials, Collectors and Locals. The basis for this spatial structuring was for the convenience of unique data collection due to differences in the density of retail outlets and human population in the study area. The zones and classes of roads are as follows;

Table 1. List of Zones and Classes of Roads

\begin{tabular}{|c|c|c|c|}
\hline S/N & ZONE & CLASS OF ROADS & ROADS \\
\hline $\mathbf{1}$ & Zone A & Arterials & Ikot Ekpene Road \\
\hline $\mathbf{2}$ & & Arterials & Atiku Abubakar Way \\
\hline $\mathbf{3}$ & & Collectors & Nkemba Road \\
\hline $\mathbf{4}$ & & Collectors & Akpan Essien Street \\
\hline $\mathbf{5}$ & & Locals & Akpan Udosen \\
\hline $\mathbf{6}$ & & Locals & Umoh Itong $^{[13]}$ \\
\hline $\mathbf{7}$ & Zone B & Arterials & Abak Road \\
\hline
\end{tabular}

\begin{tabular}{|c|c|c|c|}
\hline $\mathbf{8}$ & & Arterials & IBB road \\
\hline $\mathbf{9}$ & & Collectors & Udo Eduok Street \\
\hline $\mathbf{1 0}$ & & Collectors & Nepa Line \\
\hline $\mathbf{1 1}$ & & Locals & Okon Essien \\
\hline $\mathbf{1 2}$ & & Locals & Mkpong \\
\hline $\mathbf{1 3}$ & Zone C & Arterials & Willington Bassey way \\
\hline $\mathbf{1 4}$ & & Arterials & Ikpa road \\
\hline $\mathbf{1 5}$ & & Collectors & Nelson Mandela Road \\
\hline $\mathbf{1 6}$ & & Collectors & Urua Ekpa \\
\hline $\mathbf{1 7}$ & & Locals & Idaka Okpo \\
\hline $\mathbf{1 8}$ & & Locals & Ikot Udoro \\
\hline $\mathbf{1 9}$ & Zone D & Arterials & Nwaniba Road \\
\hline $\mathbf{2 0}$ & & Arterials & Dominic Utuk Avenue \\
\hline $\mathbf{2 1}$ & & Collectors & Ekpenyong Street \\
\hline $\mathbf{2 2}$ & & Collectors & Utang Steet \\
\hline $\mathbf{2 3}$ & & Locals & Asuquo Akpan \\
\hline $\mathbf{2 4}$ & & Locals & Utang Lane \\
\hline $\mathbf{2 5}$ & Zone E & Arterials & Oron Road \\
\hline $\mathbf{2 6}$ & & Arterials & Gen Edet Akpan Ave \\
\hline $\mathbf{2 7}$ & & Collectors & Akpan Etuk \\
\hline $\mathbf{2 8}$ & & Collectors & Uruan Street \\
\hline $\mathbf{2 9}$ & & Locals & Hospital Street \\
\hline $\mathbf{3 0}$ & & Locals & Ifa Atai Street \\
\hline $\mathbf{3 1}$ & Zone F & Arterials & Aka Road \\
\hline $\mathbf{3 2}$ & & Arterials & Sir Udoudoma Avenue \\
\hline $\mathbf{3 3}$ & & Collectors & Obio Imo Street \\
\hline $\mathbf{3 4}$ & & Collectors & Udo Umana Street \\
\hline $\mathbf{3 5}$ & & Locals & Affia Etoi lane \\
\hline $\mathbf{3 6}$ & & Locals & Ibiono Street \\
\hline & & & \\
\hline
\end{tabular}

Source: Researcher, 2016.

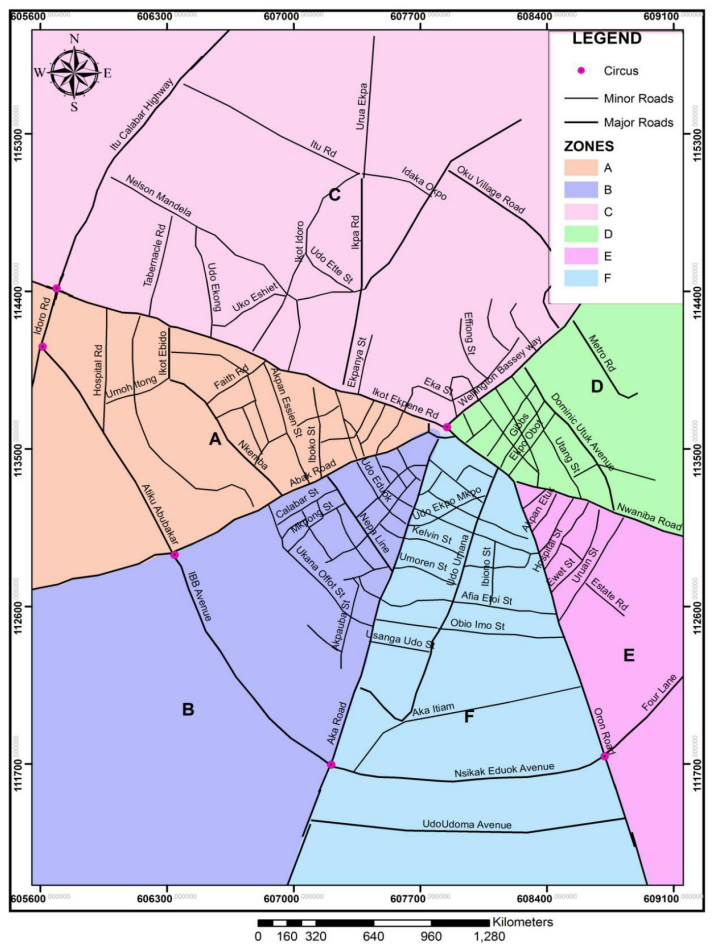

Figure 3. The Study Area and Sampled Zones on the Map of Uyo Urban

Source: Researcher, 2015 
The simple random sampling technique was adopted in selecting locations in the zones for choosing the respondents and administering questionnaire in each location. These responses were limited to respondents from both genders that are 18 years and above who have lived for at least a year in the zone.

\subsection{Data Sets}

Due to the numerous retail outlets, and in order to make meaningful sense, retail outlets were classed into ten different groups namely; Electronic/Electrical \& Computer Appliances, Motor vehicles and spares, Food Products and Restaurants, Clothing and wearing apparels, Building materials and Furniture items, Musical Equipment, Drug and Pharmaceutical Stores, Arts and Stationeries Agro allied products and General Merchandise.

\subsection{Sampling Techniques}

A reconnaissance survey of Uyo urban was carried out, and for the convenience of data collection, the area of study was delineated into six zones according to the six major arterial ways. The area in between Ikot Ekpene and Abak Roads made up zone A, Abak and Aka Roads zone B, Ikot Ekpene Road and Wellington Bassey Way zone $\mathrm{C}$, Wellington Bassey way and Nwaniba Road zone D, Nwaniba and Oron Roads zone E, while Oron and Aka Roads made up zone $\mathrm{F}$ as adopted from research of diverse retail outlets by Sarwar, Chowdhury \& Muhibbullah ${ }^{[10]}$, Tom ${ }^{[11]}$. Furthermore, zonal delineation aided in revealing the spatiality of retail outlets in Uyo urban as compared to the popular Sector model by Hoyt ${ }^{[6]}$. Each zone as delineated had two sampled Collectors linkages, two sampled Local linkages and two sampled Arterial linkage where 10 questionnaire was administered in each with an exception of the Major Arterial road where 14 questionnaire was administered. Thus, 64 copies of the questionnaires were administered in each zone. A systematic sampling method was adopted in selecting the sampled streets. Two roads were systematically chosen based on the classes of linkages which are Arterials, Collectors and Locals. The basis for this spatial structuring was for the convenience of unique data collection due to differences in the density of retail outlets and human population in the study area.

\section{Results and Discussion}

In this study of the Location of retail outlets with distances from the city centre, we realized that apart from exceptions in Ikot Ekpene and Nwaniba road, retail outlets peaked in their first kilometer from the Central Business
District. The location of retail outlets increased in Ikot Ekpene road in 1-2 km because of the sizes of these outlets. It was observed that the sizes of retail outlets in the $1-2 \mathrm{~km}$ group were smaller and numerous.

Uyo Urban showing Location of Retail Outlets along Arterials, Collectors and Locals

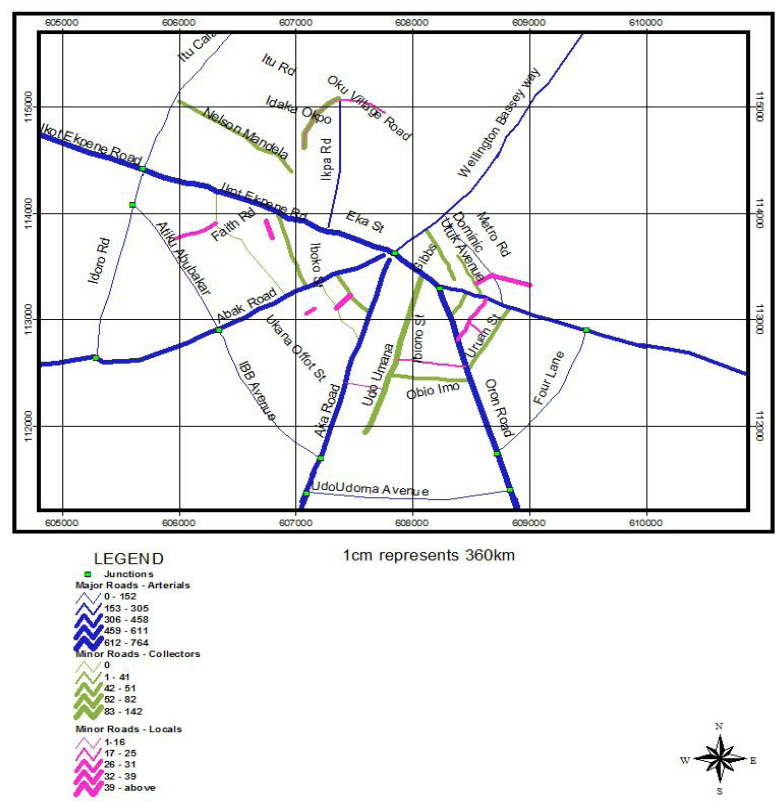

Figure 4. Location of Retail outlets along sampled Arterials, Collectors and Locals on the Map of Uyo Urban

Source: Researcher, 2016

Nwaniba Road had a higher location of retail outlets around 2-3 km from the Central Business District. It was observed that retail activities were intense here based on the location of smaller groups of traditional markets along this artery. Three individual clusters of retail outlets were identified namely; Urua Nwaniba, Urua Ekpiri Nsukara, and Urua Use.

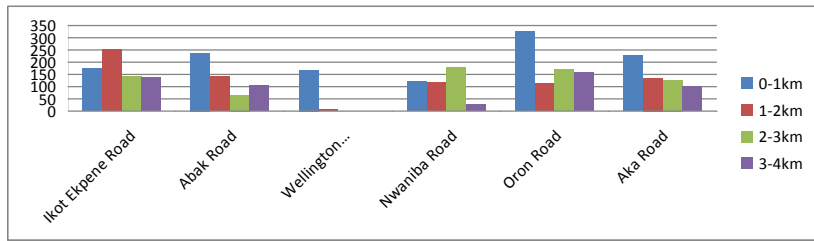

Figure 5. Distribution of Retail Outlets with distance from Central Business District

The Figure 4 above shows a ratio of the total retail outlets as located across the first, second, third and fourth kilometers from the Central Business District to be 39:24:21:16 percent of the retail outlets.

Test of Hypothesis: The hypothesis "there is no significant relationship between the distance from the central business district and the location of retail outlets" sought to understand the relationship that exists on how retail outlets were located as distance increase from the central business 
district. The distance from the Central Business Districts was measured along the six major arterial roads that link the city to the central business districts by the use of the Google Map Distance Calculator and itouch maps technology. The six arteries were divided into four distinct spaces in kilometers namely $0-1 \mathrm{~km}, 1-2 \mathrm{~km}, 2-3 \mathrm{~km}, 3-4 \mathrm{~km}$. A collection of the ten classes of retail in a zone according to their location across the four distinct spaces with the six zones participating was carried out. This summed up the total number of variables for each zone to be 40 . The distances in kilometers as measured from the Central Business District was used as the dependent variable $\mathrm{Y} 1$. The independent variables $\mathrm{X} 1, \mathrm{X} 2, \mathrm{X} 3, \mathrm{X} 4, \mathrm{X} 5$ and $\mathrm{X} 6$ were the six major arteries represented by the location of each specific retail type of outlet. Each distinct retail outlet on the artery made up $40 \mathrm{X}$ variables with an exception of Wellington Bassey Way whose length ended around the $2 \mathrm{~km}$ mark which also had 20 distinct variables. This was tested to show how the patterns of retail outlets perform with the various grouped distances from the city centre. This analysis was produced as assisted by the SPSS version 20 software.

The first table populated revealed an R-square of 47.9 percent. This was the degree of variation in the location of retail outlets as the distance increase away from the Central Business District as explained by the location of these retail outlets along the six major arteries. This means that along the six major arteries, as distance increased from the city centre there is 47.9 percent variation in retail outlets location. The correlation coefficient (R) of $69.2 \%$ reveals a strong relationship between the distances from the Central Business Districts and the location of retail outlets located across the six major arteries. This confirms what was already obvious in the data collection stage where there was a strong intensity of location of retail outlets in the city centre with a gradual decline as distance increase from the centre. Although there was an increase in intensity of retail outlets in junctions away from the Central Business Districts according to multiple nuclei concept our results still revealed a very strong correlation coefficient.

The result showing the descriptive and correlation table is shown in Appendix. This analysis reveals that the calculated value $F=1.99$ and the Significant value $=0.14$ at 0.05 significant level. Since the calculated value is higher than the significant value, we reject Ho and accept $\mathrm{H} 1$ which states that there is a relationship a significant relationship in the location of retail outlets as distance increase from the city centre across the linkages.

\section{Conclusion}

Due to the popularity of retailing in city space, more at- tention should be focused on studies concerning retail location as it relates with or affects the individuals' livability. Each retail outlets should be studied and its effects (positive and negative) revealed. This form of study will aid planners in predicting the various needs available in city space. Retail Outlets cluster around the nodes connected by linkages. As retail outlets populate and congest the central business districts and nodes close to it, there is need to create new nodes away from the populated centre to aid increase growth in suburbs and as well reduce congestion in the Central Business Districts. This confirms the practicality of multiple nuclear theory which should be adopted in city planning to ensure an even growth and expansion even in developing urban centres in Sub-Saharan Africa.

This studies also reveal that while there is an increase in digital retail innovation across city space, the importance of retail outlets accessing location has not changed. It reveals that retail outlets still cluster on highly accessible road network and closer to the central business district irrespective of the high cost of rent.

\section{References}

[1] Cochran, W. G.. Sampling techniques. 3rd ed., New York: John Wiley \& Sons, 1977: 246.

[2] Fabiyi, O.. Urban Land Use Change Analysis of a Traditional City from Remote Sensing Data: The Case of Ibadan Metropolitan Area, Nigeria. Humanity \& Social Sciences Journal, 2015, 1 (1): 42-64.

[3] GCSE Bitesize. Urban Models, 2015, accessed on $25^{\text {th }}$ November, 2016, Available at:

http://www.bbc.co.uk/schools/gcsebitesize/geography/urban_environments/urban_models_medcs_ rev1.shtml

[4] Google map developers. Distance Finder, 2015, accessed on $16^{\text {th }}$ January, 2015, Available at: http://www.mapdevelopers.com/distance_finder.php

[5] Harris, C. D. \& Ullman, E. L.. The Nature of Cities. Annals of the American Academy of Political and Social Science, 1945, 242: 7-17.

[6] Hoyt, H.. The Structures and the Growth of Residential Neighbourhood in American Cities. Chicago: Chicago University press, 1939: 320.

[7] Itouch Maps. Longitude and Latitudes of a Point, 2014, accessed on $11^{\text {th }}$ December, 2014, Available at: http://itouchmap.com/l atlong.html

[8] Knowles, R. \& Wareing, J.. Economic and Social Geography made simple. London: Made simple books W. H. Allen \& Company Ltd. 44 Hill Street, W1X 8LB, 1976: 334.

[9] McCarty, H. H. \& Linderberg, J. B.. A preface to 
Economic Geography. New Jersey: Prentice Hall, Inc, 1966: 520.

[10] Sarwar, M. I., Chowdhury M. T., \& Muhibbullah, M.. Quality of Urban Neighborhood Environment: A Case Study of Resident's Perception in Chittagong City, Bangladesh. Trends in Applied Sciences Research, 2006, 1(7): 248-258.

[11] Tom, A. A.. Residence Perception of Urban Environ- mental Quality in Uyo. Unpublished Master Thesis, Department of Geography and Natural Resources Management, University of Uyo, Nigeria, 2015.

[12] Toyne, P. \& Newby, P.. Technique in Human Geography. London: Macmillian Education 1td, 1971: 389.

[13] Udosen, C.. Gully Erosion in Ikpa River Basin: a Threshold Phenomenon. Lagos: Time Communication, 2008: 281. 